Received: 21-10-2018. Accepted: 24-12-2018. Published: 03-01-2019

\title{
Company Risk, Size, Fiscal Loss Compensation, and Tax Avoidance: Evidence from Indonesian Islamic Companies
}

Ria Triananda Putri ${ }^{1}$, Ihyaul Ulum² ${ }^{2}$ Adi Prasetyo ${ }^{3}$

Accounting Department, Universitas Muhammadiyah Malang, Malang, Indonesia ${ }^{123}$

\begin{abstract}
The purpose of this research is to examine the influence of corporate risk, company size, and compensation tax losses against tax avoidance. Sample was drawn from Jakarta Islamic Index (JII) companies. We use secondary data from Indonesia stock exchange and company's official websites. PLS-SEM was used to analyze the data, especially we use WarpPLS 6.0. The result indicates that corporate risk and size significantly influence on tax avoidance, while compensation tax losses has no impact on tax avoidance. This means that the higher of corporate risk, the higher amount of tax avoidance. The bigger size of companies, the higher amount of tax avoidance.
\end{abstract}

Keywords: Compensation tax losses; corporate risk; size, tax avoidance

\section{Introduction}

A country's development requires both financial and non-financial resources. The source of finance comes from the tax sector paid by each taxpayer. According to Mardiasmo (2000) Taxes represent a sum of money in the form of contributions to be paid by the people to state coffers based on a law that can be coercive by receiving indirect payments used to pay public expenditures. Data from the Central Bureau of Statistics 2017 showed the realization of state revenues gained from tax was reaching 1,495,893.80 Billion Rupiah, while in 2016 yielded 1,539,166.20 Billion Rupiah, it showed a decrease in revenue realization in the tax sector (www.bps.go.id). The Minister of Finance stated that the delay in the collection of tax funds is due to the large number of tax payers who practice tax avoidance and tax evasion. Tax avoidance is one way of taxpayers to make tax evasion by utilizing the weaknesses of tax laws. Such tax avoidance efforts are carried out by reducing the amount of tax payable through gaps or matters that is not yet regulated by law or known as the gray area (Praditasari and Setiawan, 2017).

Taxes avoidance done by the company definitely involve the leaders of the company as the decision maker. The decision can be seen from the risk of the company. The higher risk of a company, the more the executive tends to be a risk taker. On the contrary, the lower risk of a company, the executive tend to be risk averse. The existence of the idea if the higher risk is taken, then the higher profits will also be obtained. The risk taker properties of executives will be greater with the many advantages offered such as abundant wealth, high income, authorization or power, and promotion. In contrast to risk takers, executives with risk averse properties would prefer to avoid any form of opportunity that may pose a risk and prefer to hold most of the assets held in a relatively safe investment to avoid funding from debt, uncertainty of returns and so on.This is in line with the results of research conducted by Damayanti and Susanto (2015), that corporate risk significantly influence tax avoidance. Research related to the company size has also been widely used in recent years. One of them was done by Saifudin and Yunanda (2016) which examines the effect of firm size to tax avoidance, the research shows that the factor has no effect on tax avoidance. However, these results were different from those of Jasmine (2017) that firm size has a significant effect on tax evasion.

Fiscal loss compensation is also a factor affecting tax avoidance. Kurniasih and Sari (2013) stated that fiscal loss compensation has a negative value to tax avoidance, because the loss can reduce the tax burden in the next year within five years. As a result, in five years the company will be spared from the tax burden, because taxable profits will be used to reduce the amount of compensation losses so that the company should not avoid taxes. Saifudin and Yunanda's (2016) study also obtained the same result that fiscal loss compensation significantly affects tax avoidance

This research is very important to do, because recently many big companies that do tax evasion both legally and illegally. It is proven that tax revenues in 2017 is lower than in 2016. In addition, this research will be different from previous research because it used two proxies on the measurement of dependent variables and there is inconsistency of research results conducted by previous research. The 
researchers want to test with corporate objects listed in the Jakarta Islamic index (JII) in 2016 because it does not close the possibility of the appropriate companies Islamic law also to avoid tax (tax avoidance). Therefore the researcher wants to examine whether tax evasion is affected by corporate risk, firm size and fiscal loss compensation, with a sample of companies listed in the Jakarta Islamic index (JII) of 2016.

\section{Literature Review}

This theory was first proposed by Heider in 1958, which was later developed by Kelley in 1972. According to Heider (1958) every individual is a pseudo scientist (pseudo scientist) who is always trying to find and identify information related to the reasons individuals do something. In other words, attribution theory asserts that a person is trying to explain the cause of another person or himself doing so. According to Robbins and Judge (2008) there are factors that affect a person doing something. These factors are internal and external factors. If someone does something on the basis of his own will or is controlled by himself means that person is influenced by internal factors, otherwise if under the control of others or outside environment means influenced by external factors.

Robbins \& Judge (2008) suggests that factors affecting the causes of internal and external behavior are as follows: 1) Specificity, specificity means that individuals tend to exhibit different behaviors. If such behavior is considered normal then it is considered an internal factor. Conversely, if the behavior is considered unusual then the behavior is caused by external factors; 2) Consensus, consensus means that if everyone does the same behavior in the same situation or situation. If consensus is low, then the behavior is caused internally. Conversely, if the consensus is high then the behavior is external; 3) Consistency, consistency means whether the individual always has a tendency to respond in the same way from time to time. The more consistent the behavior, then the behavior is caused internally. Conversely, the more inconsistent the behavior, then the behavior is caused externally.

From the point of view of the theory of attribution, this theory is relevant to tax research that refers to taxpayer compliance in complying with every tax law made, especially the ways used in the calculation of tax burden whether in accordance with those contained in the tax laws.

\section{Interest Theory}

The interest is used as the basis for the division of the tax burden on the people by looking at the level of interest of each person (Mardiasmo, 2000: 3). This theory states that the higher the level of interest to a country then the tax burden is also paid directly proportional. So the company should pay the tax burden in accordance with its interests. The company needs all the aspects that exist within a country in order to generate income or profit. In addition, companies in decision-making and policy are highly dependent on the state, which includes regulation, community and state stability. Conflict will occur if a large, highinterest company makes tax avoidance so that the tax burden paid to the state is not in line with its importance.

\section{Carrying Capacity Theory}

This theory suggests that the tax burden for all people must be the same weight, meaning that the tax burden paid to the state must be in accordance with the powers or burden of each person (Mardiasmo, 2000: 4). There are two approaches used to measure carrying capacity, namely: the approach of the objective element and the subjective element approach. The objective element focuses on how much income or wealth possessed, while the subjective elements see the amount of material needs that must be met.

\section{Tax Avoidance}

Tax avoidance is a tool for tax saving by transferring the resources that should be given to the state to shareholders for increased after taxes (Butje \& Tjondro, 2014). According to Prebble et al., (2012) tax avoidance is an activity in doing tax evasion by taking advantage by exploiting the existing legal weakness to minimize tax payable. Tax avoidance is an example of tax planning that can be done through the process of earnings management to reduce the imposition of taxes that are not desirable company so that the company can do tax saving. Tax avoidance action is done through tax management mechanism.

\section{Firm Risk}

Company risk is the volatility of corporate earnings, which can be measured by the standard deviation formula. Corporate risk is a deviation or standard deviation of earnings whether the deviation is less than planned (downsiderisk) or more than the planned (potential upset), the greater the standard deviation of earnings of the company indicates the greater the risk of existing companies. The high and low 
risk of this company indicates the executive character whether including risk taker or risk averse Each company has a leader who occupy the top position both as top executives and top managers, where each leadership has certain characters to provide direction in running business activities in accordance with the purpose the company wants to achieve (Butje and Tjondro, 2014). Low (2006) stated that in carrying out his duties as chairman of the company, the executive has two characters as a risk taker and risk averse. Executives with risk taker characters are bolder executives in business decisions and usually have stronger impulses for higher income, position, welfare, and authority, in contrast to risk takers, executives with risk averse characters are exemplars who tend not to likes risk so less daring in taking business decisions. An executive with a risk averse character if he gets a chance he will choose a lower risk.

\section{Firm Size}

The size of the firm is a scale that classifies the company in terms of total assets, total sales, number of labor, and others (Saifudin and Yunanda, 2016). This definition is almost identical to the previously stated definitions. Total assets and sales amount to be a measure of company size. Based on several definitions, it can be seen that the size of the company is a scale that determines the size of the company that can be seen from the value of equity, sales value, number of employees, total assets, and others.

\section{Fiscal Loss Compensation}

The compensation of loss in income tax is provided in Article 6 paragraph (2) of the Income Tax Law No.17 of 2000. As for some important points to note in the case of compensation of these losses are as follows: a) The term "loss" refers to a fiscal loss not a commercial loss. Fiscal losses or gains are the difference between income and expenses that have taken into account income tax provisions; b) Loss compensation is only allowed for the next five years in a row. If at the end of the fifth year there is still a loss remaining then the remaining losses can no longer be compensated. c) Loss compensation is only for corporate and personal tax payers who engage in business activities whose income is not subject to Final Income Tax and the income tax calculation does not use the norm of calculation. d) Loss of business abroad can not be compensated with income from within the country.

\section{Methodology}

This type of research is associative research because it aims to prove and analyze the relationship of a variable with other variables. In this study the relationship between variables of causality between dependent variables and independent variables. The population in this study are all companies registered in Jakarta Islamic Index (JII) in 2016. The method of determining the sample used in this study is the purposive sampling method. This study uses secondary data types when viewed from how to obtain it. Data in the form of corporate financial statements contained in Jakarata Islamic Index (JII) in 2016, as well as data sources obtained by researchers obtained from the official website of the Indonesia Stock Exchange and the company website which became the object of this study. Techniques used are documentation by looking at the financial statements, notes on financial statements, and annual reports of all companies listed on the JII (Jakarta Islamic Index) in 2016. The data are obtained from the official website of the company and the official website of the Indonesia Stock Exchange (www.idx.co .id).

\section{Tax Avoidance}

According to Dyreng (2010) this variable is calculated through CUETR (current effective tax rate) of the company that is the cash issued for current tax cost divided by profit before tax. The greater CUETR indicates the lower rate of corporate tax evasion. In addition to using CUETR, this study also uses ETR (effective tax rate) proxy as its measurement ratio. According to Ambarukmi and Diana (2017) ETR is a measure of how effectively a company manages its tax burden by comparing the tax burden on total income. CUETR and ETR ratios can be formulated as follows:

$$
\begin{aligned}
& \text { CUETR }=\frac{\text { The current income tax }}{\text { Profit before income tax }} \\
& \text { ETR }=\frac{\text { Income tax expense }}{\text { Profit before income tax }}
\end{aligned}
$$

\section{Company Risk}

To know the corporate risk owned, it can be measured by the standard deviation formula. The greater company's earnings deviation indicates the greater its risk. The measurement of the risk of this 
company is calculated through the standard deviation of EBITDA (Earning Before Income Tax, Depreciation, and Amortization) divided by total assets of the company.

$$
\text { RISK }=\sqrt{\sum_{T-1}^{T}\left(E-1 / T \sum_{T-1}^{T} E\right)^{2} /(T-1)}
$$

\section{Company Size}

Ferry and Jones (1979) define corporate size as a big picture of a company. The corporate size described in the total assets of the company is measured in rupiah. Size variable is measured using Natural logarithm total assets owned by the cororate. So the ratio of corporate size is formulated as follows:

Company Size $=\operatorname{Ln}($ total asset)

\section{Fiscal Loss Compensation (RFIS)}

The fiscal loss compensation in this research is measured using dummy variables, which will be given a value of 1 if there is fiscal loss compensation in year $t$ (Sari and Martani, 2010) and a value of 0 if no fiscal loss compensation is provided in year $\mathrm{t}$.

Techniques or stages of data analysis of this study is using the method of Structural Equation Modeling (SEM) analysis. The analysis program used is Partial Least Square (PLS). The choice of this method is due to several reasons thatare, able to measure the variable that can not be measured directly like dummy. PLS does not require normal distribution in tested data and not constrained by the number of samples because in this study the sample used is small, it will be more efficient when using SEM-PLS (Sholihin and Ratmono, 2013). In addition, the dependent variable is using two indicators, as well as analyzing the reflective and formative measurement model, in this study has analyzed formative variable rather than refletive. The use of SEM-PLS method aims to explain the constructs or latent variables. The analysis used in data processing is descriptive statistics, data quality test and hypothesis test.

\section{Result and Discussion}

Evaluation of PLS model is done by evaluating outer model and inner model. Outer model is a measurement model to assess the validity and reliability of data. Inner model is a structural model to predict relations between latent variables or between constructs (Abdillah and Hartono, 2015). .This test was measured using the Structural Equation Model-Partial Least Square (SEM-PLS) program with the help of WarpPLS 6. The data quality test consisted of a construct validity test and a reliability test. The next stage, assessing the inner model or structural model. The purpose of assessing the model with PLS is to see Rsquare for each latent dependent variable. Changes that occur in R-square values can be used in assessing the effect of independent latent variables on latent dependent variables. In addition to view the R-Square values, the PLS model is also evaluated by looking at the Full collinearity VIF and Q-Square predictive relevance. Full collinearity VIF is a full test result that includes vertical multicoliearity, lateral and common method bias, whereas Q-Square predictive relevance is used to measure how well the observation value is generated by the model and also its parameter estimation. The value of the Full collinearity VIF should be below 3.3 (Sholihin and Ratmono, 2013).

Test of reliability in PLS can be done with two methods, namely Cronbach's alpha and composite reliability, this study only use composite reliability because the data used is not gained from questionnaire. When using composite reliability, a construct is said to be reliable if its value $>0.7$ although a value of 0.6 is still acceptable (Hartono and Abdillah, 2014: 61-62). The sample determination will be described in the table below:

Table 1. Sample Selection

\begin{tabular}{lll}
\hline Description & Amount \\
\hline 1. & $\begin{array}{l}\text { Companies registered in Jakarta Islamic Index (JII) period } \\
\text { December 2016 until May 2017. }\end{array}$ & 30 \\
\hline 2. & $\begin{array}{l}\text { Companies that do not publish annual reports complete with } \\
\text { periods ending December 2016. }\end{array}$ & $(2)$ \\
\hline 3. & $\begin{array}{l}\text { Companies that use currencies other than the rupiah in their } \\
\text { reporting periods ending December 2016. }\end{array}$ & $(4)$ \\
\hline
\end{tabular}


Based on the above table 1, companies listed in JII period December 2016 until May 2017 are as many as 30 companies. There are two companies that do not publish an annual report complete with period ending of December 2016 namely PT. Sawit Sumbermas Sarana Tbk and PT. Mitra Keluarga Karyasehat Tbk. Companies that are excluded from the sample because using currencies other than the rupiah is PT. Adaro Energy Tbk, PT. Vale Indonesia Tbk, PT. Perusahaan Gas Negara (Persero) Tbk, and Unilever Indonesia Tbk.

Descriptive analysis in this study describes each research variable by using the minimum, maximum, average (mean) and standard deviation. Descriptive variables consist of 24 sample data from the companies in JII from December 2016 to May 2017. Descriptive statistics of all variables including minimum, maximum, mean, and standard deviation are presented as follows:

Table 2. Indicator of Tax Avoidance

\begin{tabular}{lccccc}
\hline & N & Minimum & Maximum & Mean & Std. Deviation \\
\hline CUETR & 24 & 0,008 & 0,487 & 0,246 & 0,141 \\
\hline ETR & 24 & 0,000 & 0,726 & 0,220 & 0,172 \\
\hline Company Risk & 24 & 0,000 & 0,116 & 0,030 & 0,029 \\
\hline Company Size & 24 & 29,070 & 32,822 & 30,854 & 0,858 \\
\hline Fiscal Loss Compensation (RFIS) & 24 & 0,000 & 1,000 & 0,458 & 0,509 \\
\hline
\end{tabular}

Table 2 indicate that indicator of tax avoidance (CUETR) has a minimum value of 0.008 that indicates the probability of tax avoidance, and a maximum value of 0.487 indicates a low probability of tax avoidance. And a mean value of 0.246 indicates that the average effective rate of tax management by firms with standard deviation of 0.141 . Meanwhile, the ETR (another indicator of tax avoidance) has a minimum value of 0,000 which indicates the greater likelihood of tax avoidance, and the maximum value of 0.726 which indicates a small probability of tax avoidance, and the mean value of 0.220 indicates the average effective tax management by firms with standard deviation of 0.172 .

The independent variables consist of company risk, firm size and fiscal loss compensation. The minimum risk of the firm 0,000 indicates that the smaller properties of risk taker owned by the executives, the smaller chance firms to do tax avoidance, and the maximum value of 0.116 indicates that the executives have risk taker properties are more likely to tax avoidance, and the mean of 0.030 indicates the average value of the variable corporate risk with standard deviation of 0.029 . The minimum value of 29,070 on firm size indicates that the smaller chance of firms to do tax avoidance, and the maximum value of 32,822 indicates that the big size of the firms taking tax avoidance measurement, and the mean value of 30,854 indicates the average firm size with standard deviation of 0.858 .

Fiscal loss compensation has a minimum value of 0,000 indicates that the company does not disclose fiscal loss compensation allowing less tax avoidance to be made, while a maximum value of 1,000 indicates that the company discloses fiscal loss compensation which indicates a greater chance of tax avoidance. The mean value of 0.458 indicates that the average compensation of fiscal losses made by companies with standard deviation of 0.509 .

Data quality test in this research using SEM-PLS with WarpPLS 6.0 application. Data quality analysis is done by evaluating the measurement value (outer model) and the structural model (inner model). Measurement of models is used to assess validity and reliability. While structural models used for predicting relationships between latent variables or between constructs (Sholihin and Ratmono, 2014).

\section{Evaluation of Structural Model (Inner Model)}

In this study, the value of Adjusted R-Square of 0.231 rounded to 0.23 indicates that the independent variables, such as corporate risk, firm size, and fiscal loss compensation can explain the variation of tax avoidance rate change by $23 \%$ an the remaining $77 \%$ influenced by other variables in outside of this research model. Furthermore, the value of $\mathrm{Q}_{2}$ of 0.231 is greater than 0 is indicating that the model estimation has good predictive validity, since the value of $\mathrm{Q}_{2}$ is greater than 0 (Sholihin and Ratmono, 2014). The value of full collinearity of VIF in variable tax avoidance is 1.095 , while the exogenous variable of company risk is 1.095, firm size and fiscal compensation are 1.089 and 1.092 respectively. It shows that all the independent variables of the vertical, lateral, and common case bias of vertical, because the full collinearity value of VIF is below 3.3. The following is the result of the structural model evaluation in this study. 
Tabel 3. Adjusted R-Squared

\begin{tabular}{c|c}
\hline Construct Eksogen & Original Sample $(\mathrm{O})$ \\
\hline Company Risk & 0,043 \\
\hline Company Size & 0,183 \\
\hline Fiscal Loss Compensation & 0,006 \\
\hline
\end{tabular}

Test results shows that the significance value $(\mathrm{P})$ is equal to or less than 0.05 , that is $\mathrm{P}=0.05$. It can be concluded that $\mathrm{H}_{1}$ is accepted. The beta coefficient value of 0.29 means that one company risk coefficient will affect the tax avoidance rate. Company risk in this research is able to influence tax avoidance because CEO or top executive in this research sample is more risk taker that tend to dare in taking a decision related to company policy. The risk of a company like this proves attribution theory that the individual does something based on internal and external factors so that in this case (the research) shows the company doing tax avoidance action. The results also support research conducted by Damayanti and Susanto (2015) and Rangkuti et al. (2017) states that corporate risk affects tax avoidance.

Test results shows the significance value $(\mathrm{P})$ is smaller than 0.05 , that is $\mathrm{P}<0.01$, so it can be concluded that $\mathrm{H}_{2}$ is accepted. The beta coefficient value of 0.46 means that one coefficient of firm size will affect the tax avoidance rate. The results of this study are in line with previous research conducted by Jasmine (2017), the same results also obtained by Ngadiman and Puspitasari (2014). This is because the big companies have tax experts who are tasked to find ways to reduce the tax burden that increases with the addition of corporate assets because large companies are able to manage taxes by tax planning as to achieve optimal tax saving. This result contradicts the theory of interests and carrying power that is the basis of taxation, because companies that have a large total asset should also contribute greater in paying taxes.

Test results shows the significance value $(\mathrm{P})$ is greater than 0.05 , that is $\mathrm{P}=0.33$. The beta coefficient value is 0.09 . Based on the significance value $(\mathrm{P})$, it can be concluded that $\mathrm{H}_{3}$ is rejected. The results of this study contradict the research conducted by Saifudin and Yunanda (2016) and Ginting's research (2016) which stated that fiscal loss compensation significantly affects tax avoidance. Fiscal loss compensation has no effect on this research because firms have better profitability, so that firms have less fiscal loss compensation value. This is seen with higher CUETR. This research supports Munandar, Nazar, and Khairuninisa (2016) research which states that fiscal loss compensation has no effect on tax avoidance.

\section{Conclusion, suggestion and limitation}

Based on hypothesis test stated that company risk and company size have significant effect to tax avoidance action. Fiscal loss compensation has no effect on tax avoidance measures. Limitations in this study are Adjusted R-Square testing, the company's independent risk variable, firm size and fiscal loss compensation are only able to explain the dependent tax avoidance variable of $23 \%$, which means $77 \%$ are influenced by other factors outside of the studied. Suggestions for further research is to use other variables that can influence tax avoidance. Subsequent research is expected to use the proxy of other measures on the dependent and independent variable from this research.

\section{References}

Abdillah, W., dan J. Hartono. (2015). Partial Least Square (PLS) Alternatif Srructural Equation Modeling (SEM) dalam penelitian Bisnis, edited by D. Prabantini: Penerbit ANDI, 1-263.

Ambarukmi, K. T., dan N. Diana. (2017). "Pengaruh Size, Leverage, Profitability, Capital Inttensity Ratio Dan Activity Ratio Terhadap Effective Tax Rate (ETR)". Junal Ilmiah Riset Akuntansi, Vol. 6, No. 17, hlm: 13-26.

Butje, S., dan E. Tjondro. (2014). "Pengaruh Karakter Eksekutif Dan Koneksi Politik Terhadap Tax Avoidance". Tax \& Accounting Review, Vol. 4, No. 2, hlm: 1-9.

Cahyono, D. D., R. Andini, dan K. Raharjo. (2016). "Pengaruh Komite Audit, Kepemilikan Institusional, Dewan Komisaris, Ukuran Perusahaan (Size), Leverage (DER) Dan Profitabilitas (ROA) Terhadap Tindakan Penghindaran Pajak (Tax Avoidance) Pada Perusahaan Perbankan Yang Listing Bei Periode Tahun 2011 - 2013". Journal Of Accounting, Vol. 2, No. 02, hlm: 1-10.

Candra, S. A. 2017. "Sri Mulyani: Pajak Terhambat Penyimpanan Dana di Tax Haven". Republika, 05 Juni 2017. 
Damayanti, F., dan T. Susanto. (2015). "Pengaruh Komite Audit, Kualitas Audit, Kepemilikan Institusional, Risiko Perusahaan Dan Return On Assets Terhadap Ax Avoidance". Jurnal Bisnis dan Manajemen, Vol. 5, No. 2, hlm: 187-207.

Dharma, N. B. S., dan N. Noviari. (2017). "Pengaruh Corporate Social Responsibility dan Capital Intensity Terhadap Tax Avoidance". Jurnal Akuntansi, Vol. 18, No., hlm: 529-556.

Dyreng, S. D. (2010). "The Effects of Executives on Corporate Tax Avoidance". The Accounting Review, Vol. 85, No. 4, hlm: 1163-1189.

Ghozali, I. (2016). Aplikasi Analisa Multivariete dengan Program IBM SPSS 23, edited by p. P. Harto. Semarang: BP Universitas Diponogoro, 474.

Ginting, S. (2016). "Pengaruh Corporate Governance Dan Kompensasi Rugi Fiskal Terhadap Penghindaran Pajak Dengan Ukuran Perusahaan Sebagai Variabel Moderating". Jurnal Wira Ekonomi Mikroskil, Vol. 6, No. 02, hlm: 165-176.

Harto, U. H. d. P. (2014). "Analisis Pengaruh Kompensasi Eksekutif, Kepemilikan Saham Eksekutif dan Preferensi Risiko Eksekutif Terhadap Penghindaran Pajak Perusahaan". Journal Of Accounting, Vol. 3, No. 2, hlm: 1-11.

Internasional, D. N. P. d. K. E., dan B. Indonesia. (2017). "sumber daya pembangunan" www.bappenas.go.id. Diakses pada 25 Oktober 2017.

Jasmine, U. (2017). "Pengaruh Leverage, Kepelimikan Institusonal, Ukuran Perusahaan, dan Profitabilitas Terhadap Penghindaran Pajak (Studi Pada Perusahaan Manufaktur Yang Terdaftar Di BEI Tahun 2012-2014)". JOM Fekon, Vol. 4, No. 1, hlm: 1786-1800.

Keuangan, M. (2000). Undang-undang Pajak Penghasilan No.17 Tahun 2000. Jakarta Direktorat Jenderal Pajak.

Kurniasih, T., dan M. M. R. Sari. (2013). "Pengaruh Return on Assets, Leverage, Corporate Governance, Ukuran Perusahaan Dan Kompensasi Rugi Fiskal Pada Tax Avoidance". Buletin Studi Ekonomi, Vol. 18, No. 1, hlm: 257-270.

Maharani, I. G. A. C., dan K. A. Suardana. (2014). "Pengaruh Corporate Governance, Profitabilitas dan Karateristik Eksekutif Terhadap Tax Avoidance". Jurnal Akuntansi, Vol. 2, No. 2, hlm: 128-140.

Mardiasmo. (2000). Perpajakan. Yogyakarta: ANDI, 284.

Merslythalia, D. R., dan M. S. Lasmana. (2016). "Pengaruh Kompetensi Eksekutif, Ukuran Perusahaan, Komisaris Independen, Dan Kepemilikan Institusional Terhadap Tax Avoidance". Jurnal Ilmiah Akuntansi dan Bisnis, Vol. 11, No. 2, hlm: 1-8.

Munandar, R, T. Nazar, M, R. dan Khairunnisa. (2016). "Pengaruh Ukuran Perusahaan, Leverage, Dan Kompensasi Rugi Fiskal Terhadap Tax Avoidance". e-Proceeding of Management, Vol. 3, No. 3, hlm: 3417-3424.

Ngadiman, dan Puspitasari. (2014). "Leverage, Kepemilikan Institusional, dan Ukuran Perusahaan Terhadap Penghindaran Pajak (Tax Avoidance) Pada Perusahaan Sektor Manufaktur Yang Terdaftar Di Bursa Efek Indonesia 2010-2012". Jurnal Akuntansi, Vol. 18, No. 03, hlm: 408421. 
Company Risk, Size, Fiscal Loss Compensation and Tax Avoidance ... (Putri, Ulum. Prasetyo) 